\title{
A New Species of Ehretia, Ehretia retroserrata in Nujiang County, Yunnan Province, China
}

\author{
Shaoyong Yang1, Fan $\mathrm{Du}^{2 *}$, Ruinian $\mathrm{Li}^{2}$, Dan Zhou ${ }^{2}$, Zhaoqiang $\mathrm{Hou}^{2}$ \\ ${ }^{1}$ Faculty of Landscape Architecture, Southwest Forestry University, Kunming, China \\ ${ }^{2}$ Forestry College, Southwest Forestry University, Kunming, China \\ Email: lamb@swfc.edu.cn, ${ }^{*}$ kmdufan@163.com
}

Received 4 January 2015; accepted 22 January 2015; published 26 January 2015

Copyright (C) 2015 by authors and Scientific Research Publishing Inc.

This work is licensed under the Creative Commons Attribution International License (CC BY).

http://creativecommons.org/licenses/by/4.0/

(c) (i) Open Access

\begin{abstract}
On the investigation of the biodiverisities of plant resources of Nujiang River Valley in Nujiang Autonomous Prefacure, Yunnan Province, China, a new species of Ehretia has been described and illustrated as Ehretia retroserrata in the arid valley of Nujiang according to the new living state of erect shrub and the characteristics of serrate leave margin, retrose, apiculate, endocarp divided at maturity into 4 1-seeded pyrene and serrate leaves margins by comparison with other species of the genus Ehretia.
\end{abstract}

\section{Keywords}

Ehretia, Ehretia retroserrata, Serrate, Retrose, Apiculate, Characteristics, Nujiang County, Yunnan Province, China

\section{Introduction}

There are 14 species in genus Ehretia in China. Most of them are arbors more than 10 meters high. There are 7 species in Yunnan Province and all of them are arbors. Among all the species of genus Ehretia in China, only E. changjiang and E. asperula are climbing shrubs in Hainan Province. On the identification research of Eheria, firstly, 2 groups have been classified according to the differences between "serrate leaves; endocarp divided at maturity into 2 2-seeded pyrenes” and “entire leaves margins, endocarp divided at maturity into 4 1-seeded pyrenes", so that E. acuminata, E. corylifolia and E. dicksonii have been classified as the $1^{\text {st }}$ group and the $2^{\text {nd }}$ group includes E. confinis, E. tsangi, E. dunniana and E. longiflora etc. Secondly, in the $1^{\text {st }}$ group, according to ${ }^{*}$ Corresponding author. 
the differences of "glabrous leaves, antrorse, apiculate teeth; corolla lobes longer than tube; drupes 3 - 4 mm in diam” and "abaxially pubescent leaves, spreading teeth, not apiculate; corolla lobes shorter than tube; drupes 6 $15 \mathrm{~mm}$ in diam", E. acuminata and E. corylifolia have been classified as 2 species. E. changjiang and E. asperula are only climbing shrubs found in Hainan Province, but their leaves are leathery and have entire margins and pubescent cymes [1]-[4]. Another species of Japan, E. microphylla has the unique characteristic of long obovate leaves with white seta and white basal plate.

\section{Materials \& Methods}

Specimens have been collected by Fan Du on June 2, 2014 on the $30^{\circ}$ slope in the dry red soil with $40 \%$ limestone naked in Mangkuan, Dai and Yi National Xiang, Longyang District, Baoshan City, in the arid valley of Nujiang Prefecture, Yunnan Province, China, with the south altitude of 807 m, E25 38'25.1" and N9852'25.1".

By taxonomy and comparative anatomy methods, the following result shows.

\section{Result \& Discussion}

Erect shrubs, 3 m tall, bark gray, branchlets brown, with longitudinal angles, Leaves papery, green, echinulatus young and glabrous mature, ovate or obvotae, basal broad cuneate and truncate, length 3 - $6.5 \mathrm{~cm}$, width 2 - 4 $\mathrm{cm}$, apex acuminate or caudate, petiole 5 - $10 \mathrm{~mm}$, width $1 \mathrm{~mm}$. $1^{\text {st }}$ veins $5-7$ pairs, araised on the lower epidermal, $2^{\text {nd }}$ and $3^{\text {rd }}$ veinlets reticulate net, leaves margins irregular serrulate, retrose, apiculate.

Terminal cyme, length $3-8 \mathrm{~cm}$, width 2 - $7 \mathrm{~cm}$, flower small, white, calyx 5 lobed, puberulent, triangular, length 1.5 - $2 \mathrm{~mm}$, width 1 - $2 \mathrm{~mm}$. Superior ovary, ovoid, diameter $1 \mathrm{~mm}$. Style termianl, 2-cleft on the upper 1/5, stigma 2, capitate. Corrola funnel-form, 5 lobed, lobe elliptic or obovate, width $2 \mathrm{~mm}$, length $3 \mathrm{~mm}$, reflex, pubescent, tube length $5 \mathrm{~mm}$, filament 6 - $7 \mathrm{~mm}$, usually exserted, anthers linear, length $2 \mathrm{~mm}$. Drupes sphere, subglobose, diameter 3 - $4 \mathrm{~mm}$, glabrous, orange, endocarp divided at maturity into 4 1-seeded pyrenes [5]-[8].

1. According to the index of genus Ehretia, erect shrub is a new characteristic among all the species while $E$. changjiangensis and E. asperula are Climbing shrubs in Hainan Province and the other species are arbors, mostly higher than $10 \mathrm{~m}$ [2].

2. The differences between "Leaves margins entire, endocarp divided at maturity into 4 1-seeded pyrenes" and "Leaves margins serrate, endocarp divided at maturity into 2 2-seeded pyrenes" are for identifying Ehretia acuminata and other species [2] [3]. However, E. retroserrata has the new characteristics of "Leaves margins serrate, endocarp divided at maturity into 4 1-seeded pyrenes”.

3. The most conspicuous characteristic of E. retroserrata is: "front serrate retrorse, apiculate", which is a compensation to the other species of "Leaves glabrous, teeth antrorse, apiculate; corolla lobes longer than tube; drupes 3 - $4 \mathrm{~mm}$ in diam” and "Leaves pubescent abaxially, teeth spreading, not apiculate; corolla lobes shorter than tube; drupes 6 - 15 mm in diam” [2]. So it has been named. Here we would no doubt the miracles of nature and the sequences of God creating the world.

\section{Conclusions}

Ehretia S. S Yang \& F. Du, sp. Nov (Figure 1)

Ehetia retroserrata S. S Yang \& F. Du, sp. nov is a new species of genus Ehretia found in the arid valley of Nujiang Valley, in a very narrow area near tillage land, and only several plants have been found in a limestone shrubs in an extremely dry ecological state. It has the characteristics of small leaves, small flowers and small drupes and indumentum developed like E. changjiang and E. asperula in Hainan Province. The arid ecology is similar to that of the two later species in Hainan Province, and they have the similar characteristics of shrubs instead of arbors. E. retroserrata has the new characteristic of erect shrub, serrate leaves margins, endocarp divided at maturity into 4 1-seeded pyrenes and glabrous leaves, teeth retrose (Figure 2 \& Figure 3), apiculate corolla lobes shorter than tube, drupes 3 - $4 \mathrm{~mm}$ in diam, puberulent calyx, pilose style, pubescent corrola lobes, leaves oil glands.

Finally, the biological protection should be emphasized and adopted in case of endangerment by the tillage.

\section{Acknowledgements}

Thanks to the herbarium of KUN and SWFC for the identification helps. 


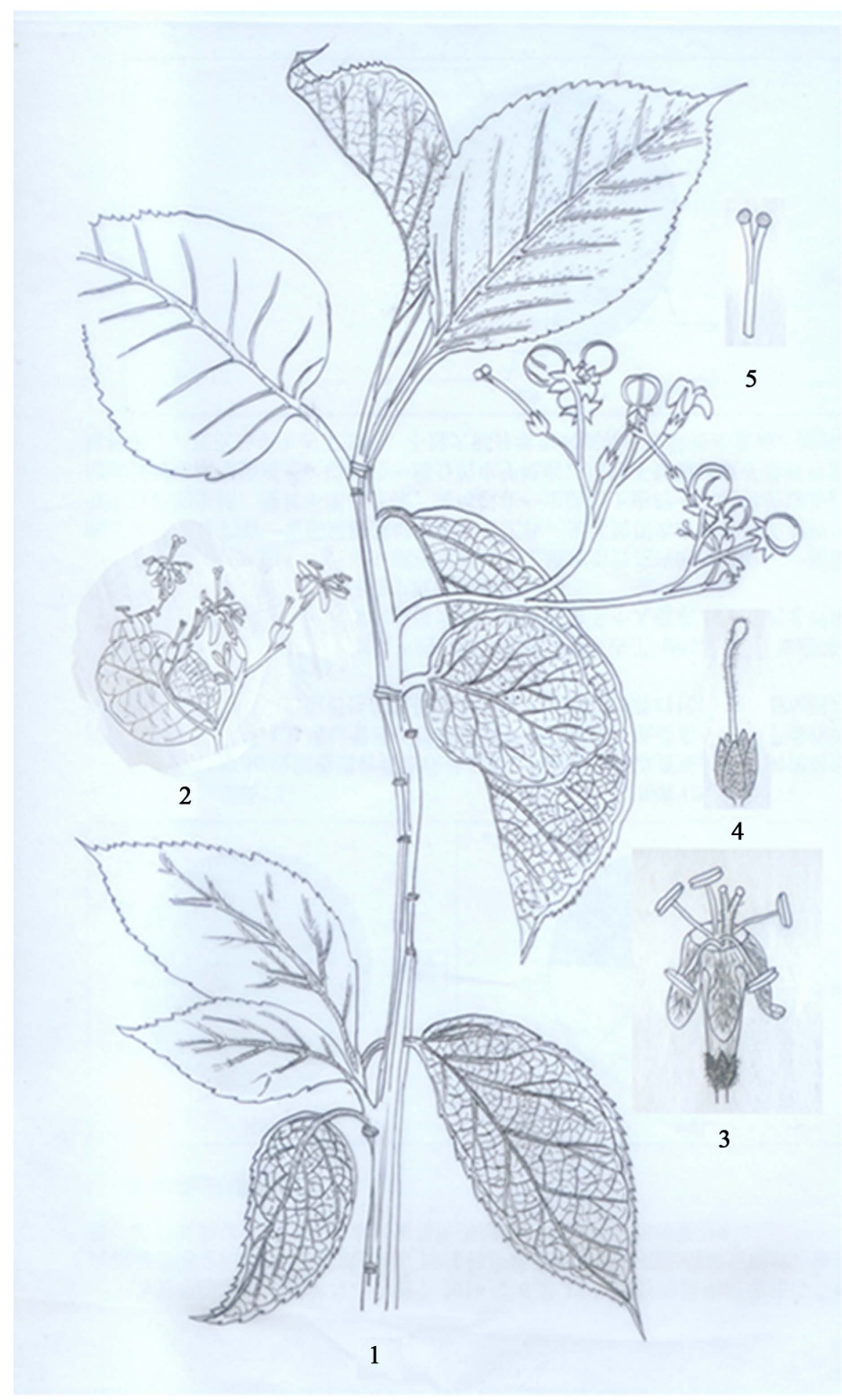

Figure 1. Eheria retroserrata S. S Yang \& F. Du, sp. Nov, drawn by Shaoyong Yang. 1. Branch and infructescence; 2. inflorescence; 3. Flower; 4. Calyx and style; 5. Stigma.

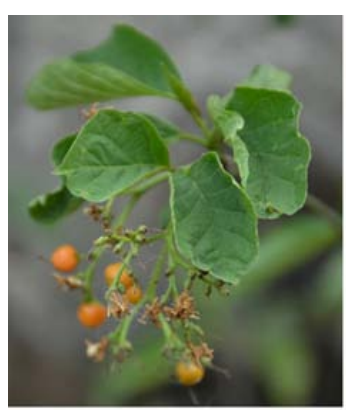

inflorescence

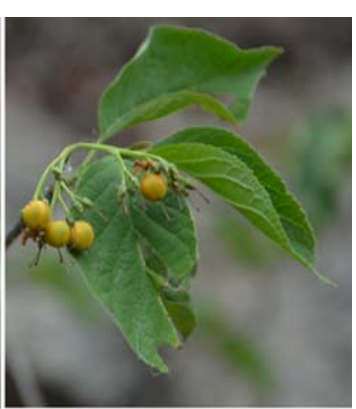

infructescence

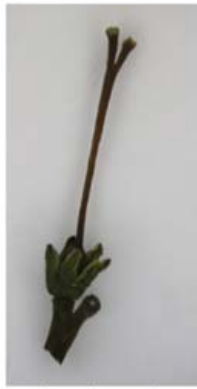

calyx \& style

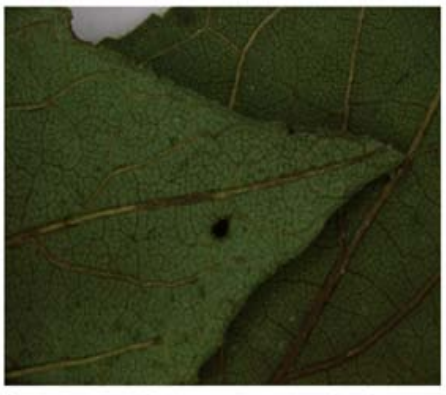

leaves margins retrose, apiculate

Figure 2. The organs of flowers \& leaves etc. 


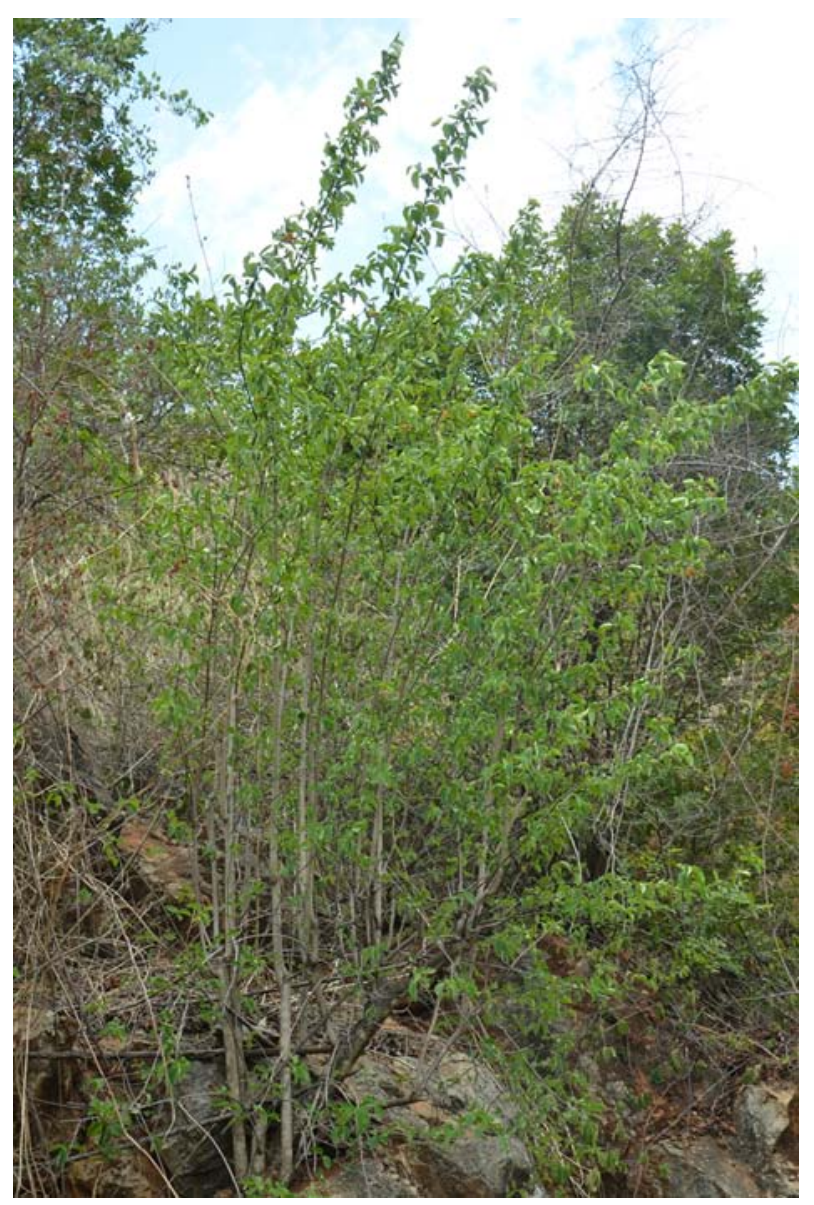

Figure 3. Erect shrub.

\section{References}

[1] Agenda Academiae Sinicae Edita (1989) Delectis Florae Reipublicae Popularis Sinicae, Flora Reipublicae Popularis Sinicae, Agenda Academiae Sinicae Edita, Tomus 64(2), Science Press, Beijing, 11-19.

[2] Flora of China Editorial Committee (1995) Flora of China. Vol. 16, Science Press \& Missouri Botanical Garden. http://foc.eflora.cn/

[3] Academiae Sinicae Edita Institutum Botanicum Kunmingense (1989) Institutum Botanicum Kunmingense, Flora Yunnanica Tomus 4, Academiae Snicae Edita. Science Press, Beijing, 675-686.

[4] Institute of Botany, Chinese Academy of Sciences (1974) The Picture Index of Senior China Plant. Science Press, Beijing, 545-546.

[5] Harris, J.G., and Harris, M.W., Translated by Wang, Y.F., Liang, C.Z. and Feng, G.P., et al. (2001) Plant Identification Terminology: An Illustrated Glossary. Science Press, Beijing.

[6] Ma, K.P. and Liu, B. (2009) Field Guide to Wild Plants of China. Higher Education Press, Shandong.

[7] Fedorov (1959) Illustrated Anatomy of organs of Higher Plants. Science Press, Beijing.

[8] Huang, P.H. and Sun, H.Z. (2005) A Common Glossary of Description to Plant Taxa in Chinese-English-Latin. Northeast Forestry University Press, Harbin, 